\begin{tabular}{c} 
JCEBT, 5 (1) maret 2021 ISSN 2549-6379 (Print) ISSN 2549-6387 (Online) \\
JCEBT \\
Oournal of Civil Engineering, Building and Transportation) \\
Available online http://ojs.uma.ac.id/index.php/jcebt \\
\hline
\end{tabular}

\title{
EVALUASI PERHITUNGAN BANGUNAN ATAS JEMBATAN KOMPOSIT
}

\section{BUILDING CALCULATION EVALUATION OF COMPOSITE BRIDGE}

\author{
Harsan Ingot Hasudungan, Nurmaidah \\ Program Studi Teknik Sipil, Fakultas Teknik \\ Universitas Medan Area, Indonesia \\ Corresponding author: harsan.sitompul@yahoo.com
}

\begin{abstract}
Abstrak
Jembatan mrupakan bagian dari jalan yang sangat berpengaruh terhadap kelancaran transportasi yang menghubungkan antara jalan Tanjung Selamat dengan jalan Beras Sekata Kecamatan Sunggal Kabupaten Deli Serdang. Jembatan ini memiliki panjang 24 meter dan lebar total 7,30 meter. Penelitian ini bertujuan untuk Mengevaluasi Perhitungan Bangunan Atas Jembatan Komposit dan mengetahui kemampuan kapasitas nominal Bangunan Atas berdasarkan SK SNI 03-2874-2002, SNI T-2004 dan Pembebanan Untuk Jembatan menggunakan SK SNI 1725:2016. Kapasitas nominal berdasarkan SK SNI 03-20874-2002, SNI T-2004 pada evaluasi slab tebal $200 \mathrm{~mm}$, jarak tulangan terhadap sisi luar slab lantai yaitu $35 \mathrm{~mm}$, sehingga lebar efektif slab $165 \mathrm{~mm}$. Momen ultimit rencana $\mathrm{Mu}=54,74 \mathrm{kNm}$ dan momen lapangan tumpuan ultimit rencana $\mathrm{Mu}=48,63 \mathrm{kNm}$. Untuk tulangan lentur negativ tulangan yang digunakan arah melintang D25-40 mm dan arah memanjang D19-10, untuk tulangan lentur positif tulangan yang digunakan arah melintang D25-40 mm dan arah memanjang D19-10. Dari perhitungan digunakan shear connector dengan diameter D 13-20 dengan Jumlah shear connector dari tumpuan sampai 1/4L adalah 46 buah jadi satu gelagar didapat = 92 buah shear connector.
\end{abstract}

Kata kunci : Jembatan, Komposit, Baja, Tulangan

\begin{abstract}
The bridge is a part of the road which is very influential on the smooth transportation that connects the Tanjung Selamat road with the Rice Road Sekata Sunggal District, Deli Serdang Regency. This bridge has a length of 24 meters and a total width of 7.30 meters. This study aims to evaluate the calculation of the building of the Composite Bridge and determine the ability of the nominal capacity of the building based on SNI Decree 03-2874-2002, SNI T-2004 and Imposition for Bridges using SK SNI 1725: 2016. Nominal capacity based on SNI Decree 03-20874-2002, SNI T-2004 on the evaluation of $200 \mathrm{~mm}$ thick slab, reinforcement distance to the outside edge of the floor slab is $35 \mathrm{~mm}$, so that the effective width of the slab is $165 \mathrm{~mm}$. The ultimate moment of your plan $=54.74 \mathrm{kNm}$ and the ultimate moment of the plan for your ultimate plan $=48.63 \mathrm{kNm}$. For negative reinforcement reinforcement reinforcement used transverse direction D25-40 mm and longitudinal direction D19-10, for positive bending reinforcement reinforcement used transverse direction D25-40 mm and longitudinal direction D19-10. From the calculation used a shear connector with a diameter D 13-20 with the number of shear connectors from the pedestal up to 1 / $4 \mathrm{~L}$ is 46 pieces so one girder is obtained $=92$ pieces of shear connector.
\end{abstract}

Keywords: Bridge, Composite, Steel, Reinforcement

How to Cite: Harsan,Nurmaidah evaluasi perhitungan bangunan atas jembatan atas komposit JCEBT (Journal of Civil Engineering, Building and Transportation). 5 (1): 26-36 


\section{PENDAHULUAN}

Jembatan yang merupakan sarana penghubung antara daerah, setiap tahun mengalami perkembangan seiring dengan meningkatnya jumlah penduduk dan tingkat perekonomian di sekitar daerah tersebut.

Untuk mengevaluasi lantai jembatan dilakukan dengan metode perencanaan struktur beton, yaitu metode beban kerja (working stress method) dan metode beban batas (ultimate limit states method) dengan mengacu kepada SK SNI 03-28742002, jembatan (SNI T-12-2004), pembebanan untuk jembatan (SNI 1725:2016). Tujuan mengetahui kemampuan kapasitas nominal Bangunan Atas berdasarkan SK SNI 03-2874-2002, SNI T-2004 dan Pembebanan Untuk Jembatan menggunakan SK SNI 1725:2016. Serta Menentukan apakah kondisi Bangunan Atas Jembatan Komposit masih layak fungsi atau tidak dari kemampuan layananya.

Jembatan komposit adalah jembatan yang mengkombinasikan dua material atau lebih dengan sifat bahan yang berbeda dan membentuk satu kesatuan sehingga menghasilkan sifat gabungan yang lebih baik. Jembatan komposit yang umum digunakan adalah kombinasi antara bahan konstruksi baja dengan beton bertulang, yaitu dengan mengkombinasikan baja sebagai deck (gelagar) dan beton bertulang sebagai plat lantai jembatan. Perencanaan komposit mengasumsikan bahwa baja dan beton bekerjasama dalam memikul beban yang bekerja, sehingga akan menghasilkan desain profil/elemen yang lebih ekonomis. Selain itu struktur komposit juga mempunyai beberapa keunggulan diantaranya adalah lebih kuat (stronger) dan lebih kaku (stiffer) daripada struktur non-komposit.

Ada dua jenis tipe jembatan komposit yang umum digunakan sebagai desain, yaitu tipe multi girder bridge dan ladder deck bridge. Penentuan pemilihan jenis jembatan yang akan digunakan tergantung pada pertimbangan ekonomi dan faktor spesifik dari medan konstruksi seperti akses transportasi menuju lapangan dan jenis dari tiang penyokong yang berada ditengah bentang.

Jembatan dengan multi girder deck menggunakan beberapa baja girder memanjang (longitudinal girder) yang ukuran dan jenisnya sama disusun dengan jarak yang sama sepanjang lebar jembatan. Komponen atau bagian dari jembatan multi girder adalah sebagai berikut:

Girder utama pada umumnya menggunakan plate girder profil I, namun untuk jembatan dengan bentang yang kecil memungkinkan juga untuk menggunakan universal beam yaitu baja dengan profil 
yang memiliki dimensi yang universal dan biasa di pabrikasi oleh berbagai perusahaan baja.

Ada tiga jenis perkuatan yang dimiliki oleh multi girder bridge. Berikut penjelasannya:

- Support Bracing

Support bracing adalah perkuatan yang berada di kedua ujung jembatan yaitu didaerah perletakan, teknis perkuatan dengan biasa menggunakan profil baja L yang disusun melintang menghubungkan antara satu girder dengan girder lainnya. Fungsi dari perkuatan ini adalah untuk stabilitas jembatan dan alat transfer beban horizontal (beban angina dan gaya selip) kebantalan yang menyediakan tahanan transversal yang terletak pada daerah perletakan jembatan.

- Intermediate Bracing

Intermediate bracing biasa disebut juga dengan diafragma jembatan yaitu berupa pelat yang menghubungkan antara girder pada arah memanjang jembatan. Fungsi dari diafragma adalah untuk menjaga girder supaya tidak melekuk atau memuntir akibat dari bebanyang dipikul oleh baja girder.

\section{- Plan Bracing}

Plan bracing biasa disebut dengan ikatan angina adalah ikatan yang menyilang pada bagian bawah jembatan, dua lokasi kemungkinan perletakan plan bracing berada diatas flens atas (terhubung ke cleat pada flens atas) dan dibawah flens atas.

1. Kelebihan dasar yang dihasilkan dari desain struktur komposit adalah sebagai berikut:

a. Kekuatan lebih seragam pada berbagai arah.

b. Dapat digunakan untuk meningkatkan kekerasan material.

c. Luas baja yang digunakan lebih sedikit.

d. Tinggi konstruksi berkurang, sehingga dapat menghemat biaya.

e. Bobot ringan dan tahan korosi.

2. Kekurangan jembatan komposit

a. Desain dan konstruksinya memerlukan spesialis yang sangat mengetahui mengenai desain rekayasa dan disiplin ilmu material.

b. Walaupun ringan namun hal tersebut juga dapat membuat aerodinamis struktur yang tidak stabil.

Konstruksi komposit bekerjan batangbatang stuktural yang merupakan gabungan dari 2 material yaitu baja struktural dan beton bertulang. Dengan kata lain, batang structural yang di bentuk dari 2 atau lebih material disebut kompopsit. Pada bangunan gedung dan jembatan umumnya berupa komposit dari baja strutural dan beton bertulang yang 
biasanya dipakai pada elemen balok atau dan kolom . Pada jembatan sebagian besar komposit untuk balok.

\section{METODE PENELITIAN}

Adapun lokasi penelitian evaluasi perhitungan banguan atas jembatan komposit dilakukan pada pelaksanaan proyek pembangunan Jembatan Tanjung Selamat jalan Kabupaten Deli Serdang seperti terlihat dalam gambar 1. dibawah ini. Evaluasi jembatan ini dapat dilakukan dengan mengambil data kelapangan.

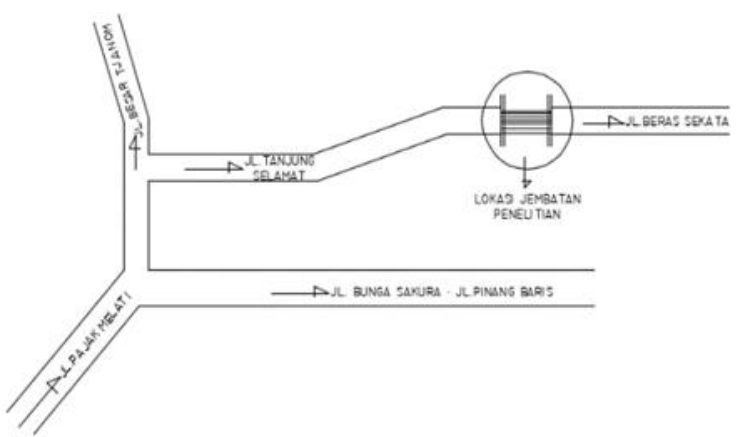

Gambar 1. Denah Lokasi Penelitian

Untuk mengevaluasi perhitungan bangunan atas jembatan komposit yang berada di jalan Tanjung Selamat, Kabupaten Deli Serdang ini diperlukan data awal jembatan yang digunakan sebagai patokan desain. Data - data tersebut antara lain :

1. Panjang Jembatan

2. Tinggi jembatan

3. Lebar jembatan
Adapun sumber data yang diperoleh pada studi kasus ini adalah sebagai berikut. Data primer merupakan yang diperoleh langsung dilapangan untuk dijadikan data dasar, namun dapat juga dijadikan pengontrol data yang sudah tersedia pada data sekunder. Data - data yang berhubungan dengan data primer meliputi data hasil survey. Data sekunder merupakan data yang diperoleh penyususnan berupa informasi tertulis atau bentuk dokumen lainya yang berupa infomasi tertulis atau bentuk dokumen lainya yang berhubungan dengan rencana proyek.

Direncanakan bangunan konstruksi Jembatan Tanjung Selamat ini memiliki panjang 24,00 meter, lebar jembatan 6 meter. Gambar desain jembatan sebagaimana terlampir pada lampiran. Crosshead girders adalah girder yang melintang tambahan yang menghubungkan dua buah girder utama dan berfungsi sebagai perletakan pada tengah bentang continuous multiple spams.

Tahapan Penelitian Beban Jembatan terlihat pada gambar 2 dibawah ini. 


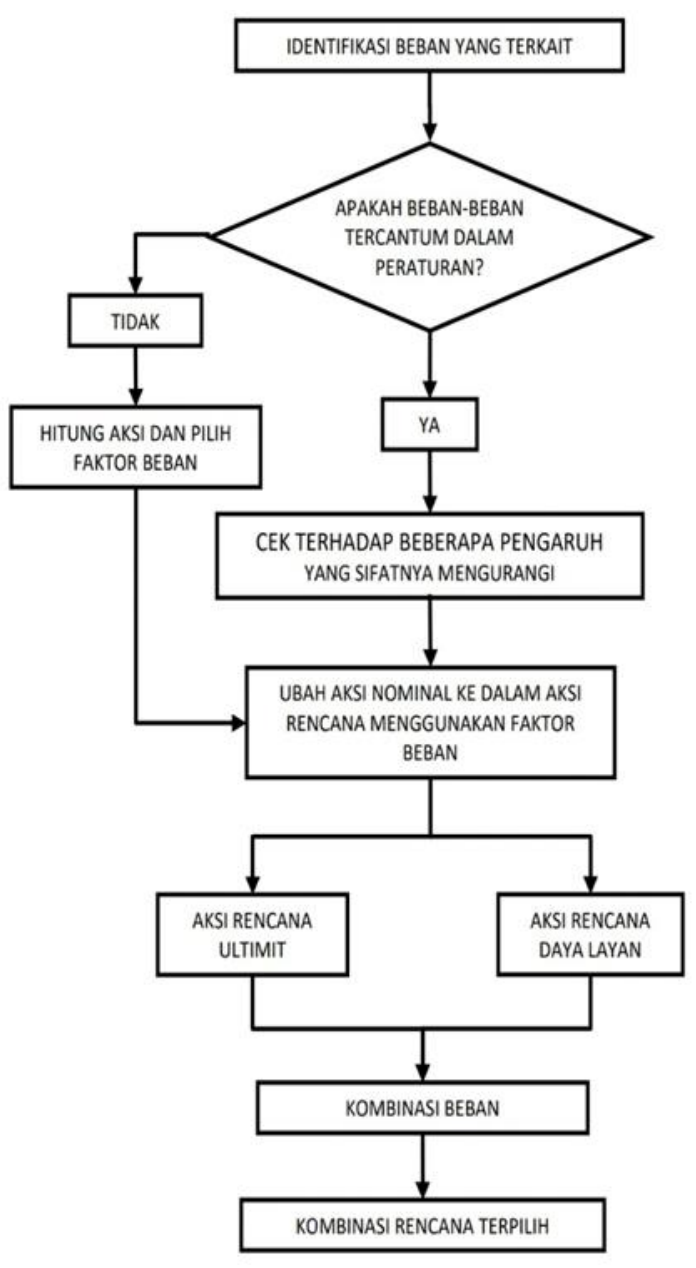

Gambar 2.Tahapan alir penelitian

\section{HASIL DAN PEMBAHASAN}

\section{Data Teknis Jembatan}

1. Data Geometris Jembatan

Tebal slab lantai jembatan

$(\mathrm{ts}=\mathrm{h})=0.20 \mathrm{~m}$

Tebal lapisan aspal +

overlay (ta) $=0.10 \mathrm{~m}$

Tebal genangan air hujan(th) $=0.05 \mathrm{~m}$ Jarak antara gelagar baja $(\mathrm{S})=1.20 \mathrm{~m}$ Lebar jalur lalu lintas (b1) $\quad=6.00 \mathrm{~m}$ Lebar total jembatan (b) $\quad=7.30 \mathrm{~m}$ Panjang bentang jembatan $(\mathrm{L})=24 \mathrm{~m}$ Lebar trotoar (b2) $=0.50 \mathrm{~m}$

2. Data Material

\section{a. Beton}

Mutu beton $\mathrm{K}-300=300 \mathrm{Kg} / \mathrm{cm}^{2}$

Kuat tekan beton $\mathrm{fc}^{\prime}=0.83 \times \mathrm{K} / 10$

$$
\begin{aligned}
& =0.83 \times 300 \\
& =24.9 \mathrm{Mpa}
\end{aligned}
$$

Modulus elastisitas

$$
\begin{aligned}
\mathrm{Ec} & =4700 \times \sqrt{\mathrm{fc}^{\prime}}=4700 \times \sqrt{24.9} \\
& =23452.95 \mathrm{Mpa}
\end{aligned}
$$

Angka poisson $\mathrm{v}=0.2$

Modulus geser

$$
\begin{aligned}
\mathrm{G} & =\mathrm{Ec} /[2 \times(1+\mathrm{v})] \\
& =23452.95 /[2 \times(1+0.2)] \\
& =9772.063 \mathrm{Mpa}
\end{aligned}
$$

Koefisien muai panjang beton $\alpha=$

$$
10 \times 10^{-6} \text { per }{ }^{0} \mathrm{C}
$$

b. Mutu Baja

Mutu baja

Tegangan leleh baja (fy)

Tegangan dasar (fs)

Modulus elastisitas baja (Es) $=210000$

c. Specific Grafity

Berat beton bertulang $(\mathrm{Wc})=25 \mathrm{kN} / \mathrm{m}^{3}$

Berat b.tidak bertulang $\left(\mathrm{Wc}^{\prime}\right)=22 \mathrm{kN} / \mathrm{m}^{3}$

Berat aspal $(\mathrm{Wa})=22.00 \mathrm{kN} / \mathrm{m}^{3}$

Berat air $(\mathrm{Ww})=9.8 \mathrm{kN} / \mathrm{m}^{3}$

Berat baja $(\mathrm{Ws})=78.5 \mathrm{kN} / \mathrm{m}^{3}$

\section{Analisa Beban Slab Lantai Jembatan}

\section{Berat Sendiri (MS)}


Faktor beban ultimit $\mathrm{K}_{\mathrm{MS}}=1.30$ (Beton dicor ditempat) Ditinjau slab lantai jembatan selebar $(b)=1000 \mathrm{~mm}$

Tebal slab lantai jembatan $(\mathrm{h})=200 \mathrm{~mm}$ Berat beton bertulang

$$
(\mathrm{Wc})=25.00 \mathrm{kN} / \mathrm{m}^{3}
$$

Berat sendiri $\left(\mathrm{Q}_{\mathrm{MS}}\right)=\mathrm{b} \times \mathrm{h} \times \mathrm{Wc}$

$$
\begin{aligned}
& =1000 \times 200 \times 25 \\
& =25 \mathrm{kN} / \mathrm{m}^{3}
\end{aligned}
$$

\section{Beban Mati Tambahan (MA)}

Faktor beban ultimit $\mathrm{K}_{\mathrm{MA}}=2.00$ (Umum)

Beban Lapisan aspal + overlay

= Tebal Aspal x Berat jenis Aspal

$=0.10 \mathrm{~m} \times 22.00 \mathrm{kN} / \mathrm{m}^{3}$

$=2.20 \mathrm{kN} / \mathrm{m}$

Beban Air hujan

= Tebal Air hujan x Berat jenis Air

$=0.05 \mathrm{~m} \times 9.8 \mathrm{kN} / \mathrm{m}^{3}$

$=0.49 \mathrm{kN} / \mathrm{m}$

Beban mati tambahan (QMA)

$=$ B. Lapisan aspal + overlay +B.Air hujan

$=2.20 \mathrm{kN} / \mathrm{m}+0.49 \mathrm{kN} / \mathrm{m}$

$=2.69 \mathrm{kN} / \mathrm{m}$

\section{Beban Truk "T" TT}

Faktor beban ultimit

$$
\mathrm{K}_{\mathrm{TT}}=1.80
$$

(Beton)

Beban hidup pada lantai jembatan berupa beban roda ganda oleh truk (beban $\mathrm{T}$ ) yang besarnya $\mathrm{T}=112.5 \mathrm{kN}$.

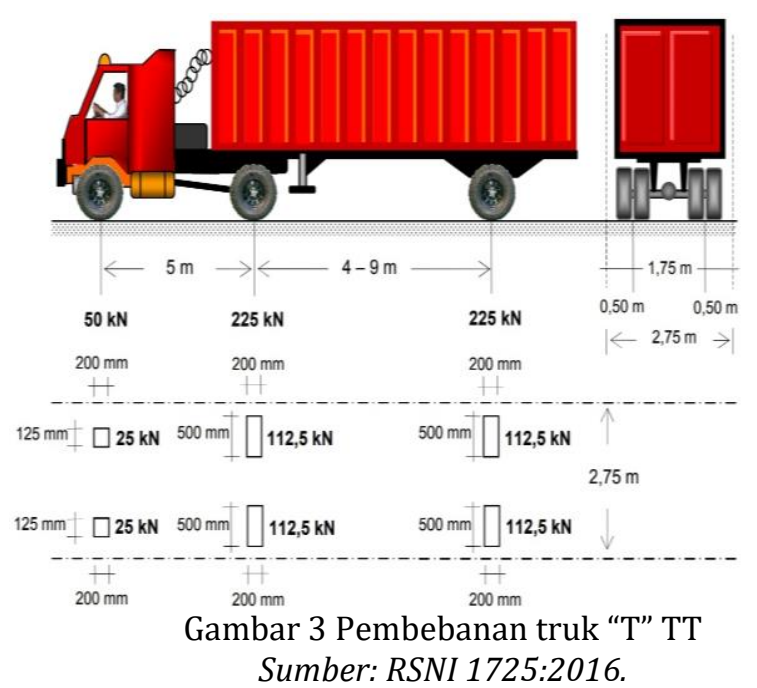

Faktor beban dinamis untuk pembebanan truk diambil FBD $=40 \%=0.40$

$$
\begin{aligned}
\text { Beban truk "T" PTT } & =(1+\text { FBD }) \times \mathrm{T} \\
& =(1+0.4) \times 112.5 \mathrm{kN} \\
& =157.5 \mathrm{kN}
\end{aligned}
$$

\section{Beban Angin (Ew)}

Faktor beban ultimit $\mathrm{K}_{\mathrm{EW}}=1,2$ (Umum koefisien serat)

Beban garis merata tambahan arah horisontal pada permukaan lantai jembatan akibat angin yang meniup kendaraan di atas jembatan dihitung dengan rumus :

$\mathrm{T}_{\mathrm{EW}}=0.0012 \times \mathrm{C}_{\mathrm{w}} \times\left(\mathrm{V}_{\mathrm{w}}\right)^{2}$

Dimana : $\mathrm{C}_{\mathrm{w}}=$ Koefisien serat 1,2 (karena $\mathrm{b} / \mathrm{d} \geq 6$ )

$\mathrm{V}_{\mathrm{w}}=$ Kecepatan angin rencana

$$
=35 \mathrm{~m} / \mathrm{det}
$$

$$
\begin{aligned}
\mathrm{T}_{\mathrm{EW}} & =0.0012 \times \mathrm{Cw} \times(\mathrm{Vw})^{2} \\
& =0,0012 \times 1,2 \times 35^{2} \\
& =1,764 \mathrm{kN} / \mathrm{m}
\end{aligned}
$$




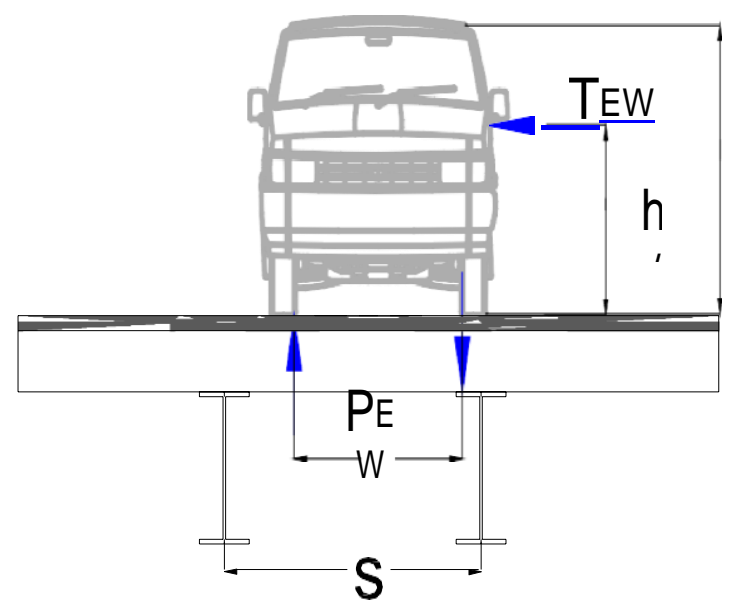

Gambar 4. Pembebanan Angin terhadap garis merata

Sumber: RSNI 1725:2016.

Bidang vertikal yang ditiup angin merupakan bidang samping kendaraan dengan tinggi $2 \mathrm{~m}$ di atas lantai jembatan $\mathrm{h}=2 \mathrm{~m}$

Jarak antara roda kendaraan $\mathrm{x}=1,20 \mathrm{~m}$

Transfer beban angin ke lantai jembatan $\left(\mathrm{P}_{\text {EW }}\right)=1 / 2 \mathrm{xh} / \mathrm{x} \times \mathrm{T}$ EW

$$
\begin{aligned}
& =\frac{1}{2} \times \frac{2}{1,20} \times 1,764 \\
& =1,47 \mathrm{kN}
\end{aligned}
$$

\section{Pengaruh Temperatur (ET)}

Faktor beban ultimit : $\mathrm{K}_{\mathrm{ET}}=1,2$ (Ketetapan)

Untuk memperhitungkan tegangan maupun deformasi struktur yang timbul akibat pengaruh temperatur, diambil perbedaan temperatur yang besarnya setengah dari selisih antara temperatur maksimum dan temperatur minimum rata-rata pada lantai jembatan.
Tabel 1. Temperatur jembatan rata - rata nominal

\begin{tabular}{lll}
\hline & Temperatur & Temperatur \\
Tipe & Jembatan Rata- & Jembatan \\
Bangunan & Rata-rata \\
Atas & (t) & Maximum \\
& & $(\mathrm{t} 2)$ \\
\hline
\end{tabular}

Lantai

beton di

atas gelagar

$15^{\circ} \mathrm{C}$

$40^{\circ} \mathrm{C}$

atau boks

beton

Lantai

beton di

atas gelagar

atau boks

atau rangka

baja

Lantai pelat

baja di atas

gelagar

boks atau

rangka baja

$$
\text { Sumber: RSNI 1725:2016. }
$$

Temperatur maks. rata-rata $\mathrm{T}_{\max }=40{ }^{\circ} \mathrm{C}$

Temperatur min. rata-rata $\mathrm{T}_{\min }=15^{\circ} \mathrm{C}$

$$
\begin{aligned}
\Delta \mathrm{T} & =\left(\mathrm{T}_{\max }-\mathrm{T}_{\min }\right) \\
& =\left(40^{\circ} \mathrm{C}-15^{\circ} \mathrm{C}\right) \\
& =25^{\circ} \mathrm{C}
\end{aligned}
$$

Perbedaan temperatur pada slab, $\Delta \mathrm{T}=$ $25^{\circ} \mathrm{C}$

Koefisien muai panjang untuk beton $\alpha=$ $0,00001 /{ }^{\circ} \mathrm{C}$

Modulus elastis beton

$\mathrm{Ec} \quad=4700 \times \sqrt{\mathrm{fc}^{\prime}}$

$$
\begin{aligned}
& =4700 \times \sqrt{24.9} \\
& =23452.95 \mathrm{Mpa}
\end{aligned}
$$

\section{Perhitungan Gelagar Jembatan}




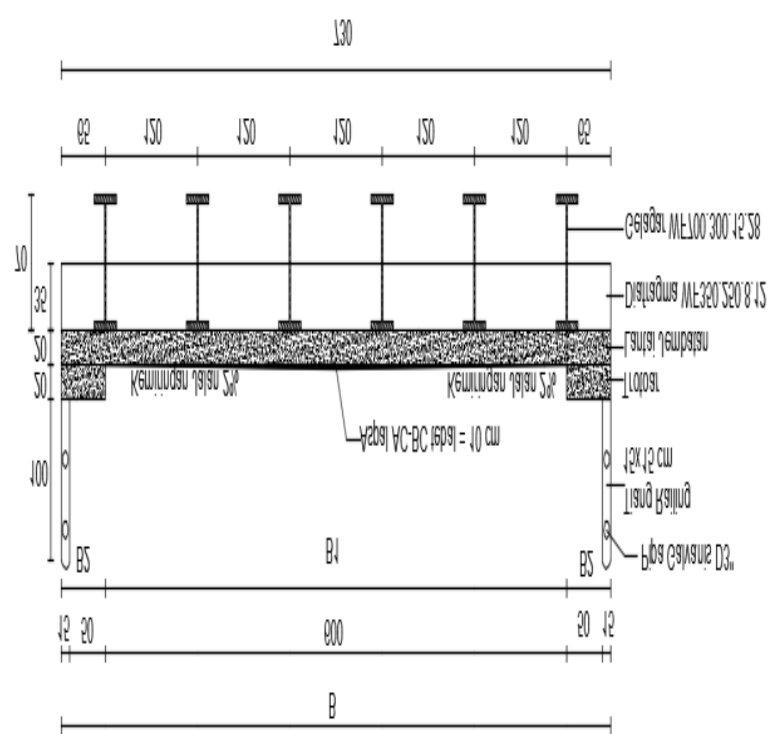

Gambar 5. Detail Gelagar Jembatan Sumber : Dinas PUPR Deli Serdang

\section{Section Properties Sebelum Komposit}

Penampang balok sebelum komposit dapat dilihat pada gambar 4.6 dibawah ini.

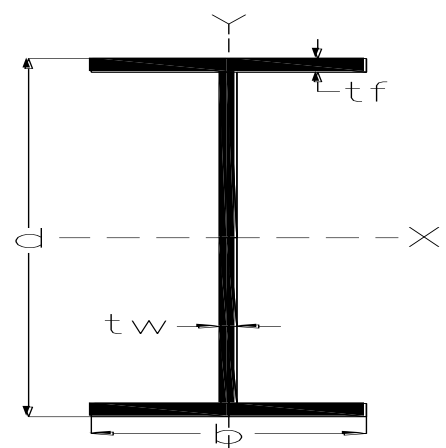

Gambar 6. Potongan Melintang Profil Sumber : Penulis

$\mathrm{L} / \mathrm{d}=24000 / 708=33,9 \mathrm{~mm}$

$1,25^{*} \mathrm{~b} / \mathrm{tf} \quad=125 / 302=13 \mathrm{~mm}$

$\mathrm{L} / \mathrm{d} \quad>1,25 * \mathrm{~b} / \mathrm{tf} \quad \mathbf{O K}$

$\mathrm{d} / \mathrm{tw} \quad=708 / 15=47,2 \mathrm{~mm}$

$\mathrm{d} / \mathrm{tw} \quad=75,0 \quad$ OK

Tegangan Izin Kip

Pada girder baja diberi pengaku smaping yang berupa balok difragma yang berfungsi sebagai pengaku samping yang merupakan dukungan lateral dengan jarak,

$$
\begin{aligned}
\mathrm{L} 1 & =\mathrm{L} / 3=24 / 3=8,000 \mathrm{~mm} \\
\mathrm{c} 1=\mathrm{L} 1 * \mathrm{~d} /\left(\mathrm{b}^{*} \mathrm{tf}\right)=(8 \times 708) /(302 \times & \\
& 28)=670 \\
\mathrm{c} 2 & =0,63^{*} \mathrm{Es} / \mathrm{fs}=0.63 \times 210000 \times 187 \\
& =709
\end{aligned}
$$

karena nilai $250<$ c1 < c2 maka: tegangan kip dihitung dengan rumus :

$$
\begin{aligned}
F_{\text {skip }}= & \mathrm{fs}-(\mathrm{c} 1-250) /(\mathrm{c} 2-250) 0,3 \mathrm{x} \text { fs } \\
= & 193-(670-250) /(709-250) \times 0.3 \\
& \quad \mathrm{x} 193 \\
= & 439.1 \mathrm{Mpa}
\end{aligned}
$$

\section{Section Properties Girder Komposit}

Rasio perbandingan modulus elastis

$\mathrm{n}=\mathrm{Es} / \mathrm{Ec}=210000 / 23453=8,95$

Luas penampang beton transforma

$$
\begin{aligned}
\text { Act } & =\text { Bef } \mathrm{xh} / \mathrm{n} \\
& =1200 \times 200 / 8.95 \\
& =26.803 \mathrm{~mm}^{2}
\end{aligned}
$$

Luas penampang komposit

Acom $=A+$ Act $=27360+26803=54.163$

$\mathrm{mm}^{2}$

Momen statis penampang terhadap sisi bawah balok

Acom $x$ ybs $=A x d / 2+\operatorname{Act} x(d+h / d)$

Jarak garis netral terhadap sisi bawah

$$
\begin{aligned}
\text { ybs }= & {[\text { Ax d/2+Act } x(d+h / 2)] / \text { Acom } } \\
= & {[27360 \times 708 / 2+26803 \times(708} \\
& +200 / 2)] / 54163 \\
= & 578,7 \mathrm{~mm}
\end{aligned}
$$

$<\mathrm{d}$ maka garis netral dibawah slab beton Jarak sisi atas profil baja terhadap garis netral

Yts $=\mathrm{d}-\mathrm{ybs}$ 


$$
=708-578,7=129,3 \mathrm{~mm}
$$

Jarak sisi atas slab beton terhadap garis

netral ytc $=\mathrm{h}+\mathrm{yts}$

$=200+129,3=329,3 \mathrm{~mm}$

Momen inersia penampang komposit:

Penampang balok setelah komposit dapat dilihat pada gambar 4.6 dibawah ini.

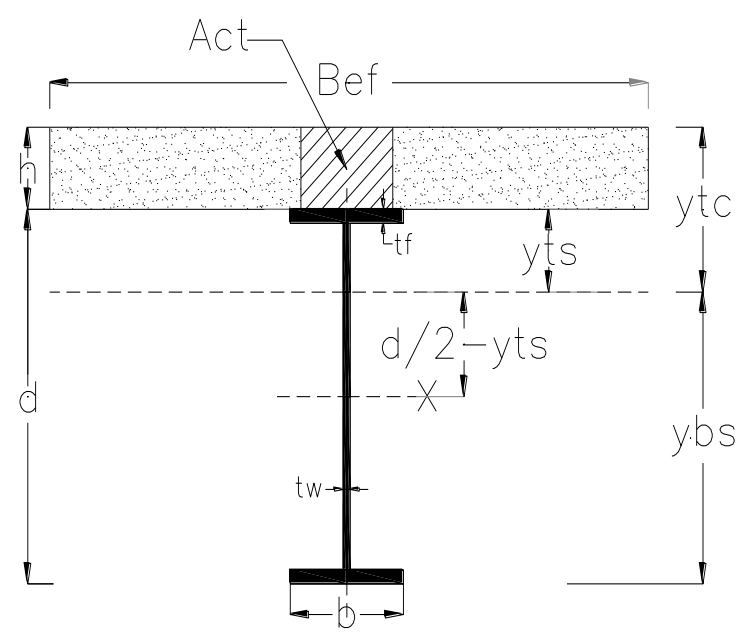

Gambar 7. Penampang Komposit Sumber : Penulis

$1 / 2 \times$ Bef $\mathrm{h}^{3} / \mathrm{n}=1 / 2 \times 1200 \times 200^{3} / 8,95$ $=536.067 .495 \mathrm{~mm}^{4}$

Act $\mathrm{x}(\mathrm{ytc}-\mathrm{h} / 2)^{2}=26803 \times(329,3-200 /$

$$
\begin{aligned}
& 2)^{2} \\
= & 1.409 .684 .544 \mathrm{~mm}^{4}
\end{aligned}
$$

$\mathrm{Ix}=2.370 .000 .000 \mathrm{~mm}^{4}$

$$
\begin{aligned}
\mathrm{Ax}(\mathrm{d} / 2-\mathrm{yts})^{2} & =27360 \times(708 / 2-129,3)^{2} \\
& =1.381 .005 .231 \mathrm{~mm}^{4}
\end{aligned}
$$$$
\text { Icom }=536.067 .495+1.409 .684 .544
$$$$
+2.370 .000 .000+1.381 .005 .231
$$$$
=5.696 .757 .270 \mathrm{~mm}^{4}
$$

Tahanan momen penampang komposit

Sisi atas beton Wtc $=\mathrm{Icom} / \mathrm{ytc}$

$$
\begin{aligned}
& =5.696 .757 .270 / 329,3 \\
& =17.297 .872,4 \mathrm{~mm}^{3}
\end{aligned}
$$

Sisi atas baja Wbs = Icom / ybs

$$
=5.696 .757 . / 578,7
$$

$\mathrm{mm}^{3}$

$=44.047 .263,8 \mathrm{~mm}^{3}$

Sisi bawah baja Wts $=$ Icom $/$ yts

$$
=5.696 .757 .270 /
$$

129,3

$$
=9.844 .618,1 \mathrm{~mm}^{3}
$$

Tegangan izin

Tegangan izin lentur beton $\mathrm{Fc}=0,4 \times \mathrm{fc}^{\prime}=$ $0,4 \times 25=9,96 \mathrm{Mpa}$

Tegangan izin lentur baja $\mathrm{Fs}=0,8 \mathrm{x}$ fs $=$ $0.8 \times 193=232,0 \mathrm{Mpa}$

\section{Kondisi Girder Sebelum Komposit}

Beban hidup sebelum komposit merupakan beban hidup pekerja pada saat pelaksanaan konstruksi diambi $\mathrm{ql}=2,00$ $\mathrm{kN} / \mathrm{m}^{2}$

Beban hidup girder sebelum komposit

$$
\mathrm{QL}=\mathrm{s} \times \mathrm{ql}=2,40 \mathrm{kN} / \mathrm{m}
$$

Total beban pada girder sebelum komposit $\mathrm{Qt}=\mathrm{QD}+\mathrm{QL}=12,99 \mathrm{kN} / \mathrm{m}$

Tegangan pada baja sebelum komposit

Panjang bentang girder $=24 \mathrm{~m}$

Momen maksimum akibat beban mati

$\mathrm{M} \quad=1 / 8 \times \mathrm{Qt} \times \mathrm{L}^{2}$

$=1 / 8 \times 12,99 \times 24^{2}$

$=935,4 \mathrm{kNm}$

$\mathrm{f}=\mathrm{Mx} 10^{6} / \mathrm{Wx}$

$$
=935,4 \times 106 / 6.700 .000
$$$$
=139,62 \mathrm{Mpa}
$$

f $<$ Fskip = 439.1 Mpa 
Lendutan pada baja sebelum komposit

$$
\begin{array}{rl}
\text { Qt } & =12,12 \mathrm{kN} / \mathrm{m} \\
\text { Es } & =210.000 .000 \mathrm{kPa} \\
\mathrm{L} & =24 \mathrm{~m} \\
\mathrm{Ix} & =0,02 \mathrm{~m}^{4} \\
\mathrm{~d} & =5 / 384 \times \mathrm{Qt} \mathrm{x} \mathrm{L}^{4} /(\text { Es } \mathrm{XIx}) \\
& =0,01 \mathrm{~m} \\
\mathrm{~d}<\mathrm{L} / 2 & 240=0,10 \mathrm{~m}
\end{array}
$$

Dapat dilihat Gambar diagram tegangan balok sebelum komposit dibawah ini

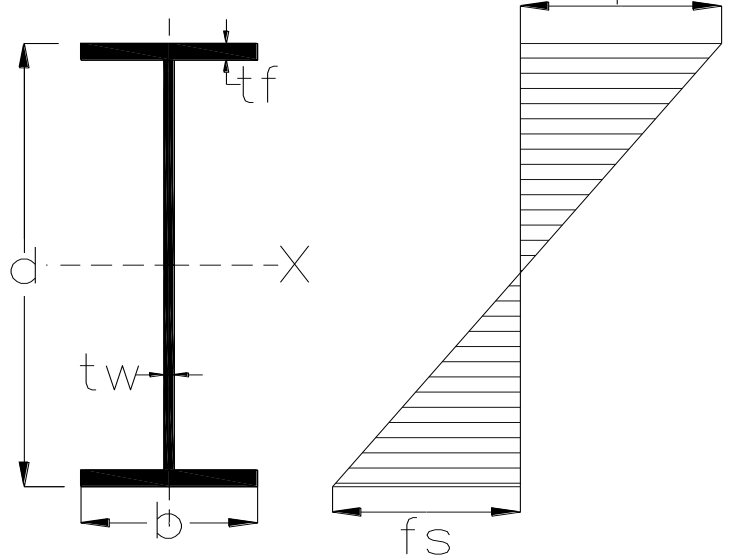

Gambar 8. Tegangan lentur yang terjadi Sumber : Penulis

\section{Kesimpulan}

Berdasarkan Evaluasi Perhitungan Bangunan Atas Jembatan Komposit besarnya beban berdasarkan SK SNI 1725:2016 yaitu berat sendiri (QMS) $=25$ $\mathrm{kN} / \mathrm{m}^{3}$, beban mati tambahan $\left(\mathrm{Q}_{\mathrm{MA}}\right)=2.69$ $\mathrm{kN} / \mathrm{m}$, beban truk “T” PTT $=157.5 \mathrm{kN}$, transfer beban angin ke lantai jembatan $\left(\mathrm{P}_{\mathrm{EW}}\right)=1,47 \mathrm{kN}$, serta perbedaan temperatur pada slab, $\Delta \mathrm{T}=25^{\circ} \mathrm{C}$ dari hasil perhitungan tersebut dapat disimpulkan bahwa beban yang dihitung masih dapat dipikul oleh jembatan Tanjung Selamat -
Sei Beras Sekata Kecamatan Sunggal dan dapat digunakan dalam pembebanan komposit jembatan. Hasil peletian perhitungan Bangunan Atas Jembatan Komposit berdasarkan SK SNI 03-208742002, SNI T-2004 pada slab tebal $200 \mathrm{~m}$, jarak tulangan terhadap sisi luar $35 \mathrm{~mm}$, sehingga lebar efektif slab $165 \mathrm{~mm}$. Momen ultimit rencana $\mathrm{Mu}=54,74 \mathrm{kNm}$ dan momen lapangan tumpuan ultimit rencana $\mathrm{Mu}=48,63 \mathrm{kNm}$. Untuk tulangan lentur negative tulangan yang digunakan arah melintang D25-40 mm dan arah memanjang D19-10, untuk tulangan lentur positif tulangan yang digunakan arah melintang D25-40 $\mathrm{mm}$ dan arah memanjang D19-10. Dari perhitungan tersebut bahawa dengan menggunakan metode SK SNI 03-20874-2002, SNI T2004 masih sama dengan perhitungan yang dilakukan oleh pembangunan jembatan Dinas PUPR deliserdang ksusunya penelitian banguan atas jembatas komposit Tanjung Selamat Beras sekata kecamtan sunggal kanan.

Dimensi gelagar induk menggunakan konstruksi baja BJ 44 (fy $=280 \mathrm{Mpa}$ ), digunakan profil WF700.300.15.28 dan Diafragma WF350,250.15.28. Dari perhitungan digunakan shear connector dengan diameter D 13-20 dengan Jumlah shear connector dari tumpuan sampai $1 / 4 \mathrm{~L}$ adalah 46 buah jadi satu gelagar didapat $=$ 
92 buah shear connector. Dari profil dan jumlah shear connector tersebut masih sangan aman digunakan dengan hasil perhitungan pembebanan berdasarkan SK

SNI 1725:2016 dan berdasarkan SK SNI 03-20874-2002, SNI T-2004.

\section{DAFTAR PUSTAKA}

DAFTAR PUSTAKA

Agus setiawan, Perencangan Struktur Beton Bertulang Berdasarkan SNI2847:2013, Buku Erlangga, Jakarta 2016.

Agus Setiawan, Perencanaan Struktur Baja Dengan Metode LRFD Edisi Kedua, Semarang 2013.

Ali Asroni, Teori dan Desain Balok Plat Beton Bertulang, MUP, Jakarta 2017.

Amrinsyah Nasution, Buku Analisa dan Desain Struktur Beton Bertulang, Bandung 2013.

Badan Standar Nasional. SNI T-12-2004 Perencanaan Struktur Beton pada Jembatan.

Dektorat Jenderal Binamarga, Departemen Pekerjaan Umum. Standar Pembebanan Untuk Jembatan (SNI 1725:2016).

Dr.Ir.Bambang Supriyadi, Agus Setyo Muntohar,ST, Buku Jembatan Cetakan KE-IV,Yogyakarta 2014.

Imran, Iswandi dan Zulkifli, Ediansjah. Perencanaan Dasar Struktur Beton Bertulang, ITB Press, Bandung 2018.

Yudha Lesmana, Analisa dan Desain Struktur Baja Berdasarkan SNI 1729:2015, Jakarta 2019

Wiyanto Dewobroto, Buku Struktur Baja, "Perilaku, Analisis \& Desain - AISC 2010" Edisi Ke-2, Bandung 2016.uli. 